\title{
RHINOLOGY
}

\section{Chronic rhinosinusitis with polyposis and serum vitamin D levels}

\author{
Rinosinusite cronica con poliposi e livelli sierici di vitamina D \\ F. BAVI ${ }^{1}$, R. MOVAHED ${ }^{1}$, M. SALEHI ${ }^{2}$, S. HOSSAINI ${ }^{1}$, M. BAKHSHAEE ${ }^{1}$ \\ ${ }^{1}$ Otorhinolaryngologist Sinus and Surgical Endoscopic Research Center, Mashhad University of Medical Sciences, \\ Mashhad, Iran; ${ }^{2}$ Clinical Research Unit, School of Medicine, Mashhad University of Medical Sciences, Mashhad, Iran
}

\section{SUMMARY}

The pathogenesis of chronic rhinosinusitis (CRS) is still unknown, but it is accepted that various inflammatory factors are responsible for the different CRS subtypes. Vitamin D3 has been shown to alter inflammatory mediators in some diseases and its deficiency might also be associated with CRS with nasal polyposis (CRSwNP). Herein, we investigated serum vitamin D3 levels in patients with CRSwNP and its association with disease severity. In a cross-sectional study, 166 cases with CRSwNP and 172 healthy subjects were enrolled. Serum vitamin D3 levels were measured and compared in both groups. Furthermore, the relationship between serum vitamin-D3 level and the patient's allergic status and severity of disease (clinically and based on computed tomographic imaging and nasal endoscopy) among patients with CRSwNP was assessed. Serum vitamin D3 level in the CRSwNP group was significantly lower than in the control group $(\mathrm{P}<0.0001)$. After controlling for possible confounding factors, an increase in vitamin D level showed a protective effect in CRSwNP $(\mathrm{OR}=0.6995 \% \mathrm{CI}: 0.62-0.76)$. A negative correlation was found between serum vitamin-D3 level and the Lund-Mackay score (LMS) $(\mathrm{P}<0.0001, \mathrm{R}=-0.66)$, the Lund-Kennedy score $(\mathrm{LKS})(\mathrm{P}<0.0001, \mathrm{R}=-0.71)$ and the Sino-Nasal Outcome Test-22 $(\mathrm{P}<0.001, \mathrm{R}=-0.49)$. Serum vitamin $\mathrm{D}$ level in the CRSwNP group was significantly lower than the control group. Disease severity, based on imaging, endoscopic and clinical criteria, was inversely associated with serum vitamin $\mathrm{D}$ levels.

KEY WORDS: Chronic rhinosinusitis $\bullet$ Vitamin D3 $\bullet$ Nasal polyposis $\bullet$ CRSwNP $\bullet$ Deficiency

\section{RIASSUNTO}

La patogenesi della rinosinusite cronica (CRS) è ancora oggetto di discussione, ma è già noto che vari fattori infiammatori siano responsabili dei diversi sottotipi di CRS. È stato dimostrato che la carenza di vitamin D3 potrebbe essere associata a CRS con poliposi nasosinusale (CRSwNP). In questo lavoro abbiamo studiato i livelli sierici di vitamina D3 nei pazienti con CRSwNP e la sua associazione con la gravità della malattia. In questo studio cross-sectional sono stati arruolati 166 casi con CRSwNP e 172 soggetti sani. I livelli sierici di vitamina D3 sono stati misurati e confrontati in entrambi i gruppi. Inoltre è stata valutata la relazione tra livello di vitamina-D3 sierica e stato allergico del paziente e gravità della malattia (clinicamente e sulla base di imaging tomografico computerizzato e endoscopia nasale) tra i pazienti con $C R S w N P$. Il livello sierico di vitamina D3 nel gruppo CRSwNP era significativamente inferiore rispetto al gruppo di controllo $(P<0,0001)$. Dopo aver controllato i possibili fattori confondenti, l'aumento del livello di vitamina D ha mostrato un effetto protettivo nei pazienti CRSwNP $(O R=0,6995 \%$ CI: 0,62-0,76). Una correlazione negativa è stata trovata tra il livello sierico di vitamina D3 e il punteggio di LundMackay (LMS) $(P<0,0001, R=-0,66)$, il punteggio di Lund-Kennedy $($ LKS $)(P<0,0001, R=-0,71)$ e il test dell'outcome sino-nasale-22 $(P<0,001, R=-0,49)$. Il livello sierico di vitamina $D$ nel gruppo $C R S w N P$ era significativamente inferiore rispetto al gruppo di controllo. La gravità della malattia, basata su imaging, criteri endoscopici e clinici, era inversamente associata al livello sierico di vitamina D.

PAROLE CHIAVE: Rinosinusite cronica $\bullet$ Vitamina D3・Poliposi nasale $\bullet$ CRSwNP $\bullet$ Carenza

\section{Introduction}

Chronic rhinosinusitis (CRS) is a chronic inflammatory disease of the paranasal sinuses. The underlying etiology of the disease is not yet fully understood. It seems that many factors including cilliary impairment, allergy, asthma, aspirin sensitivity and genetic factors are involved in the development of CRS ${ }^{1}$. Clinical symptoms consist of congestion, facial pain and pressure, anosmia, headaches, excessive mucus production and increased susceptibil- ity to acute bacterial infection of the sinuses, which may impair the quality of life. To confirm a diagnosis of CRS, symptoms must persist continuously for over 12 weeks and also include an objective sign of mucosal inflammation in computed tomography (CT) to provide a comprehensive view of the opacification within the paranasal sinuses and the nasal cavity or via the nasal endoscopy (NE) to directly visualise the nasal cavities and paranasal sinus ostia ${ }^{12}$. According to EPOS guidelines ${ }^{1}$, CRS may be divided in- 
to two subtypes, with (CRSwNP) and without (CRSsNP) nasal polyposis. Previous authors have tried to distinguish nasal polyp (NP) patients based on predominant inflammatory cell type/cytokine expression; the most common classification differentiates them into eosinophilic and non-eosinophilic CRSwNP. Increased activity of T-helper type 2 (Th2) cells leads to eosinophils recruitment and is mostly associated with CRSwNP, whereas Th1 increased activity leads to neutrophil recruitment and is more frequently associated with CRSsNP ${ }^{3-6}$.

Several studies suggest that vitamin D3 acts as a steroid hormone that has anti-inflammatory effects ${ }^{7-9}$ and plays an important role in regulating dendritic cells (DC) ${ }^{10}$. The mechanism of immune system modification by vitamin D3 is similar to other corticosteroids ${ }^{70-12}$. Various studies have shown that vitamin D3 is able to stop the production of cytokines and inhibit differentiation of immune cells. It prevents maturation and differentiation of monocytes to DCs, increases interleukin-10 production by CCs and thereby decreases DC stimulation of Th1/Th2 differentiation, resulting in higher tolerance ${ }^{13}{ }^{15}$. Active $(1,25)$ $\mathrm{OH}$-vitamin-D3 also recruits interleukin-10, producing Tregulatory cells which could help reduce inflammation. In previous studies, an inverse relationship was found between serum vitamin D levels and the level of dendritic cells in CRSwNP patients ${ }^{11}$. A similar correlation was revealed between serum vitamin D levels and the granulocyte monocyte colony-stimulating factor (GMCSF) ${ }^{16}$. Some studies suggest that local regulation of vitamin D in the sinonasal tissue during CRS may be independent of serum $25(\mathrm{OH})-\mathrm{D}$ levels and that local calcitriol and tacalcitol inhibit the synthesis of pro-inflammatory cytokines (IL-6 and IL-8) in fibroblast cultures ${ }^{17}$. A significant dose-dependent decrease in fibroblast proliferation was also observed when tissue samples were treated with calcitriol and tacalcitol ${ }^{18-20}$. In this study we aimed to compare serum vitamin D3 levels in patients with CRSwNP and healthy controls. The innovative aspect of the current study was to reveal the association between disease severity based on "imaging and endoscopic evaluations" and vitamin D3 levels, which to our knowledge has not been addressed in previous studies.

\section{Materials and methods}

This cross-sectional study was conducted in the Rhinology Clinic of Qaem and Imam Reza educational hospitals as a tertiary institute with accredited residency and fellowship program, Mashhad, Iran; from Oct 2015 to Aug 2017. The study protocol was approved by the local Ethics Committee of Mashhad University of Medical Sciences. Mashhad is a large city located in northeast- ern Iran that is almost always sunny albeit with polluted weather. The latitude longitude coordinates for Mashhad are $36^{\circ} 18^{\prime} 56.12^{\prime \prime} \mathrm{N}, 59^{\circ} 34^{\prime} 4.66^{\prime \prime} \mathrm{E}$.

All patients with signs and symptoms of CRS referred to the Rhinology clinic were evaluated and those with CRSwNP 2 were enrolled in the study. CRS was defined according to the American Academy of Otolaryngology ${ }^{2}$. All cases with these criteria who had sinonasal polyposis confirmed by CT and endoscopic evaluation were entered into the study as the study group (CRSwNP). In total, 166 patients with eosinophilic polyps were enrolled; all patients underwent history, physical examination, nasal endoscopy and sinus CT scan. Lund-Mackay ${ }^{20}$ and LundKennedy ${ }^{21}$ scores were calculated based on CT and endoscopic findings, respectively.

Skin prick testing with common local allergens as a gold standard was also done to clarify allergic status of subjects. Exclusion criteria were: history of vitamin D supplementation, anticonvulsant use, 1 or more cycle of low or high oestrogen OCP usage in last 3 months or corticosteroid use in the last 3 months. History of any chronic disease associated with low vitamin D3 serum levels such as chronic renal, cardiac, and liver diseases and malnutrition. Patients who did not consent to participation.

The control group consisted of 172 healthy subjects who did not have any symptoms suggesting chronic sinusitis or allergy and were matched with the study group in term of age, gender, ethnicity and approximate latitude and geographical location. The control group was selected from regional normal population in different lab office with check up panel without history of vitamin D medication or any related condition such as chronic diseases, asthma and allergy who were matched for sex and age.

Serum level of vitamin D3 was measured in both groups by HPLC ${ }^{33}$.

Data were analysed using the Statistical Package for Social Sciences (SPSS, version 16). Descriptive statistics were used to describe the quantitative (mean and standard deviation and mean and $95 \%$ confidence interval, CI) and qualitative variables (frequencies). The Kolmogorov-Smirnov test was used to assess normality. Baseline demographics and clinical characteristics were compared among groups using the Mann-Whitney U test and the chi-square test as appropriate. For assessing the relation between quantitative variables with normal and non-normal distribution, Pearson and Spearman correlation coefficient were used respectively.

To study the effect of vitamin D deficiency on sinonasal polyposis, independent of the role of allergy, we compared vitamin D levels in non-allergic CRSwNP patients and the control group with an independent t-test.

Multivariate analysis was performed with an Enter meth- 
od of logistic regression analysis. Confounding variables were entered into the binary logistic regression model and OR (odds ratio) with $95 \%$ CI. A P-value $<0.05$ was considered statistically significant.

\section{Results}

The mean age in the study and control groups was $41.04 \pm 13.0$ yrs and $41.00 \pm 14.8$ yrs, respectively, indicating no significant difference $(\mathrm{P}=0.98)$. The male-tofemale ratio was 98/68 and 93/79 in the study and control group respectively, with no significant difference in terms of gender $(\mathrm{P}=0.35)$. Table I shows the demographic characteristics of the case and control groups.

The mean vitamin D level in patients with CRSwNP was $12.11 \pm 6.27 \mathrm{ng} / \mathrm{ml}$ and $90 \pm 17.18 \mathrm{ng} / \mathrm{ml}$ in the control group. The difference of 23.79 (95\% CI: 21.01-26.58) was statistically significant $(\mathrm{P}<0.0001)$ (Fig. 1).

The correlation between Lund-Mackay score, Lund-Kennedy grading score and mean serum vitamin D level was assessed using Spearman's correlation test; it showed a significant negative correlation $(\mathrm{P}<0.0001$; rho $=-0.66, \mathrm{P}<0.0001$; rho $=-0.71$, respectively). The correlation between SNOT 22 and mean serum vitamin D level was assessed using Pearson's correlation test $(\mathrm{P}<0.0001 ; \mathrm{R}=-0.49)$ (Table II).

In CRSwNP patients (study group), 55 (33\%) had allergy and $52(31 \%)$ had asthma. Accordingly, there was no significant difference between vitamin D levels in non-asthmatic (12.61) and asthmatic (11.00) CRSwNP patients $[-1.61(-3.68-0.45) \mathrm{P}=0.13]$, but a significant difference was observed in vitamin $\mathrm{D}$ levels between non-allergic $(12.87 \pm 6.17)$ and allergic $(10.5 \pm 6.26)$ CRSwNP patients [-2.29 (-4.31 - -0.28) P =0.026]. Since the control group was composed of healthy people with a negative history of allergy and asthma, for controlling the possible confounding effect of allergy, again the vitamin D level among nonallergic CRSwNP (12.87 \pm 6.17$)$ individuals in comparison

Table I. Demographic data of the patient (CRSwNP) and control groups.

\begin{tabular}{|c|c|c|c|}
\hline & $\begin{array}{l}\text { CRSwNP } \\
\text { patients } \\
\mathrm{N}=166\end{array}$ & $\begin{array}{l}\text { Controls } \\
N=172\end{array}$ & $\begin{array}{c}P \\
\text { value }\end{array}$ \\
\hline $\begin{array}{l}\text { Sex (N\%) } \\
\text { Male }\end{array}$ & 98 (59\%) & 93 (54\%) & $P=0.35$ \\
\hline Age (mean 95\% Cl) & $\begin{array}{c}41.04 \\
(39.05-43.05)\end{array}$ & $\begin{array}{c}41.01 \\
(38.77-43.24)\end{array}$ & $P=0.98$ \\
\hline Smoking (N\%) & $82(49.4 \%)$ & $17(9.9 \%)$ & $P<0.001$ \\
\hline $\begin{array}{l}\text { Education (N\%) } \\
\text { Primary education } \\
\text { Academic education }\end{array}$ & $\begin{array}{l}89 \\
76\end{array}$ & $\begin{array}{c}55 \\
111\end{array}$ & $P<0.001$ \\
\hline Vitamin D (ng/ml) & $\begin{array}{c}12.11 \\
(11.15-13.07)\end{array}$ & $\begin{array}{c}35.90 \\
(33.32-38.50)\end{array}$ & $P<0.001$ \\
\hline
\end{tabular}

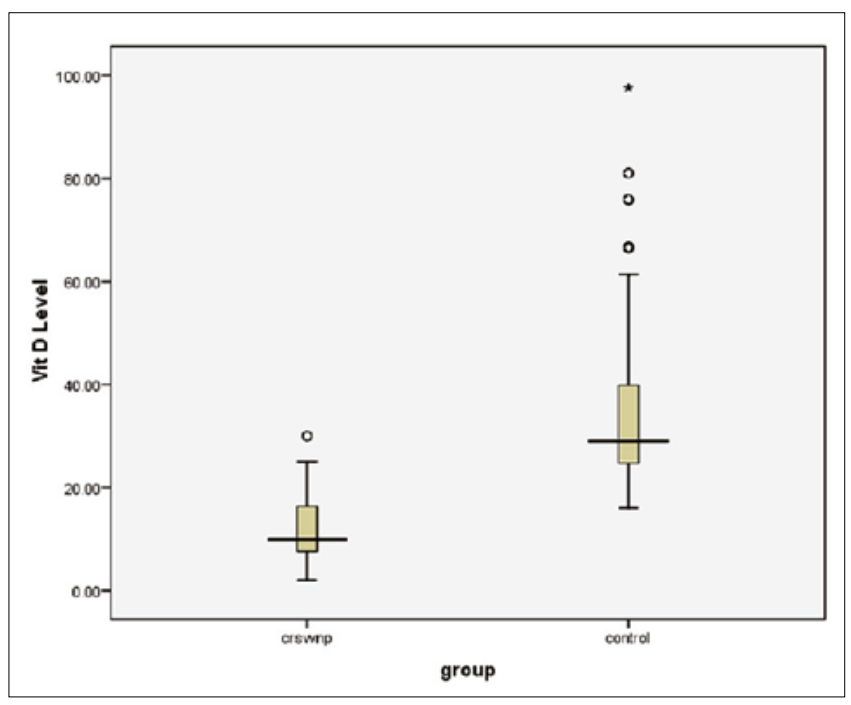

Fig. 1. Box- and -whisker display vitamin D level in the two groups.

Table II. Relationship between serum vitamin D level and Lund-Mackay (LM) score, Lund-Kennedy score, SNOT22 score.

\begin{tabular}{|c|c|c|c|c|}
\hline & Mean & $\begin{array}{c}95 \% \\
\text { confidence interval }\end{array}$ & R & $\begin{array}{c}P \\
\text { value }\end{array}$ \\
\hline $\begin{array}{l}\text { Lund-Mackay } \\
\text { score }\end{array}$ & 19.4 & 18.99-19.85 & -0.66 & $<0.001$ \\
\hline $\begin{array}{l}\text { Lund-Kennedy } \\
\text { score }\end{array}$ & 9.2 & $8.86-9.7$ & -0.71 & $<0.001$ \\
\hline SN0T22 score & 89 & $87.74-91.21$ & -0.49 & $<0.001$ \\
\hline
\end{tabular}

to healthy controls $(35.90 \pm 17.19)$ showed a significant difference $[-23.03(-26.38--19.69) \mathrm{P}=0.026]$. Thus, the patients with allergy were excluded from further analysis.

After potential risk factors (education and smoking) were entered into the model, the odds ratio for vitamin D level was $(\mathrm{OR}=23.64,95 \% \mathrm{CI}: 11.63-48.04)$. The results of the multivariate analysis are shown in Table III.

\section{Discussion}

Nowadays ethnicity is believed to play an important role in vitamin D level. Based on epidemiological studies, the prevalence of vitamin D deficiency is higher in Middle Eastern countries compared to Western nations ${ }^{23}{ }^{24}$. Accordingly, we decided to design a study with a larger sample size than previous studies to investigate the relationship between serum vitamin D levels, CRSwNP and disease severity in Mashhad, Iran $\left(\mathrm{L}=36^{\circ} \mathrm{N}\right)$.

To the best of our knowledge, this study is the first to investigate the correlation between serum vitamin $\mathrm{D}$ levels and polyposis severity in CRSwNP patients, based on "endoscopic evaluation", in addition to CT-scan grading. In addition, as far as we know, this study has the largest sample size among similar surveys having investigated the asso- 
Table III. Independent risk factors for CRSwNP in multivariate analysis.

\begin{tabular}{lccc} 
Variable & OR & CI 95\% & P value \\
Smoking positive & 1.02 & $0.36-2.88$ & 0.79 \\
Vitamin D level & 0.69 & $0.62-0.76$ & $>0.001$ \\
Education level & 1.79 & $0.46-2.79$ & 0.78 \\
\hline
\end{tabular}

ciation between vitamin D3 level and CRS. Our findings revealed a significantly lower vitamin $D$ level in patients with CRSwNP in comparison to healthy controls; severity of disease also correlated inversely with serum vitamin D levels. In addition, multivariate analysis controlled for confounding factors such as allergy, education and smoking; the effect of vitamin D3 deficiency on CRSwNP is supposedly independent of these confounding factors on CRS. Vitamin D3 has currently been shown to have many immunologic effects, especially on dendritic cells, $\mathrm{T}$ cells and macrophages ${ }^{25} 26$. Vitamin $\mathrm{D}$ receptors have been found in many cells. Rostkowska and colleagues ${ }^{20}$ found a significant dose-dependent decrease in fibroblast proliferation when tissue samples from nasal polyps were treated with various doses of vitamin D analogs. In another study by the same author ${ }^{19}$, calcitriol and tacalcitol were demonstrated to inhibit the synthesis of pro-inflammatory cytokines such as IL-6 and Il-8 in fibroblast cultures. A significant inverse correlation was also found between serum vitamin D levels and the level of dendritic cells, prostaglandin E2 and granulocyte monocyte colony-stimulating factor in CRSwNP patients by Mulligan et al. ${ }^{11}$.

These and several recent studies suggest an anti-inflammatory and immune-modulatory role for vitamin D3 in patients with CRSwNP. In the current study, this relationship in CRSwNP cases was statistically significant. Previous studies have also mostly reported this correlation as significant ${ }^{1011} 13$ 27-29, although exceptions exist ${ }^{8}$.

In the present study, only CRSwNP patients were investigated and not CRSsNP cases. Most studies found that vitamin D3 level in CRSwNP is lower than in CRSsNP patients ${ }^{1011} 1327-29$, although one study reported different results ${ }^{8}$.

Furthermore, similar to three other studies ${ }^{11} 2729$ we used CT imaging as a diagnostic factor to evaluate disease severity and found somehow similar results, showing a significant inverse correlation between disease severity and serum vitamin $\mathrm{D} 3$ levels $(\mathrm{P}<0.0001)$.

Additionally, we endoscopically assessed polyps using the LKS system, and a significant relationship was achieved between serum vitamin D3 levels and endoscopic grade of disease $(\mathrm{P}<0.0001)$.

Although the exact pathogenesis of CRSwNP is yet unknown, the available evidence suggests the same inflammatory process seen in allergic rhinitis and asthma. Some studies support the role of vitamin D3 in these two diseas- es. Given the fact that vitamin D3 has the ability to modulate the innate and adaptive immune system, its role in the pathophysiology of allergy has been the field of interest for many years. Vitamin D3 plays an important role in maintaining skin integrity and reducing pathogenic colonization in atopic dermatitis ${ }^{31}$. Yenigun et al. ${ }^{32}$ found that vitamin D3 levels in patients with allergic rhinoconjunctivitis are significantly lower compared to healthy controls. Nevertheless, 55 of our 166 (33\%) CRSwNP cases had simultaneously suffered from allergy. Therefore, we aimed to determine whether allergy may play a role in lowering the vitamin D level in this group. It could be postulated that patients with allergy avoid outdoor environments to reduce their symptoms and consequently, have lower vitamin D levels. This study shows that allergic patients have significantly lower vitamin D levels compared to non-allergic CRS individuals $(\mathrm{P}<0.026)$, confirming the proposed hypothesis. Moreover, even in non-allergic CRS individuals the level of vitamin $\mathrm{D}$ is significantly lower than healthy subjects $(\mathrm{P}<0.0001)$. Therefore, the role of vitamin D3 deficiency in CRS seems to be independent of the allergic basis.

This study had certain limitations. Many conditions play a role in the level of serum vitamin D such as skin colour, race, socioeconomic status, lifestyle, nutritional status, sun exposure during the day, use of sunscreen agents, chronic kidney and liver diseases, body mass index and others ${ }^{33}$. We matched the two studied groups in terms of race, sex, age and lack of chronic diseases, whereas other factors were not evaluated and matched between the two groups. Therefore, in order to prevent bias, it is highly recommended to assess all these conditions in future studies. Also to further approve the results of similar studies, the role of vitamin D supplementation in the treatment of CRSwNP should be considered.

\section{Conclusions}

In conclusion, a significantly lower vitamin D level was found in Iranian CRSwNP patients, indicating a positive correlation with disease severity. Serum vitamin D levels may be used as a workup in these patients and such data could be applied to further determine disease severity.

\section{Conflict of interest statement}

None declared.

\section{References}

1 Fokkens WJ, Lund VJ, Mullol J, et al. European Position Paper on rhinosinusitis and nasal polyps 2012. Rhinol Suppl 2012;23:1-298.

2 Rosenfeld RM, Piccirillo JF, Chandrasekhar SS, et al. Clinical practice guideline (update): adult sinusitis. Otolaryngol Head Neck Surg 2015;152(Suppl2):S1-S39.https://doi.org/10.1177/0194599815572097. 
3 De Corso E, Lucidi D, Battista M, et al. Prognostic value of nasal cytology and clinical factors in nasal polyps development in patients at risk: can the beginning predict the end? Int Forum Allergy Rhinol 2017;7:861-7. https://doi.org/10.1002/alr.21979.

4 De Corso E, Baroni S, Battista M, et al. Nasal fluid release of eotaxin-3 and eotaxin-2 in persistent sinonasal eosinophilic inflammation. Int Forum Allergy Rhinol 2014;4:617-24. https://doi.org/10.1002/alr.21348.

5 De Corso E, Baroni S, Romitelli F, et al. Nasal lavage CCL24 levels correlate with eosinophils trafficking and symptoms in chronic sinonasal eosinophilic inflammation. Rhinology 2011;49:174-9. https://doi. org/10.4193/Rhino10.133.

6 De Corso E, Baroni S, Lucidi D, et al. Nasal lavage levels of granulocyte-macrophage colony-stimulating factor and chronic nasal hypereosinophilia. Int Forum Allergy Rhinol 2015;5:557-62. https://doi. org/10.1002/alr.21519.

7 Sansoni ER, Sautter NB, Mace JC, et al. Vitamin D3 as a novel regulator of basic fibroblast growth factor in chronic rhinosinusitis with nasal polyposis. Int Forum Allergy Rhinol 2015;5:191-6. https://doi. org/10.1002/alr.21474.

8 Deluca HF, Cantorna MT. Vitamin D: its role and uses in immunology. FASEB J 2001;15:2579-85. https://doi.org/10.1096/fj.01-0433rev.

9 Mulligan JK, White DR, Wang EW, et al. Vitamin D3 deficiency increases sinus mucosa dendritic cells in pediatric chronic rhinosinusitis with nasal polyps. Otolaryngol Head Neck Surg 2012;147:773-81. https:// doi.org/10.1177/0194599812448852.

10 Mulligan JK, Bleier BS, O'Connell B, et al. Vitamin D3 correlates inversely with systemic dendritic cell numbers and bone erosion in chronic rhinosinusitis with nasal polyps and allergic fungal rhinosinusitis. $\mathbf{J}$ Clin Exp Immunol 2011;164:312-20. https://doi.org/10.1111/j.13652249.2011.04325.x.

11 Hackstein H, Thomson AW. Dendritic cells: emerging pharmacological targets of immunosuppressive drugs. Nat Rev Immunol 2004;4:24-34. https://doi.org/10.1038/nri1256.

12 Mulligan JK, Nagel W, O'Connell BP, et al. Cigarette smoke exposure is associated with vitamin D3 deficiencies in patients with chronic rhinosinusitis. J Allergy Clin Immunol Pract 2014;134:342-9. https://doi. org/10.1016/j.jaci.2014.01.039.

13 Litonjua AA, Weiss ST. Is vitamin D deficiency to blame for the asthma epidemic? J Allergy Clin Immunol Pract 2007;120:1031-5. https://doi. org/10.1016/j.jaci.2007.08.028.

14 Weiss ST, Litonjua AA. Childhood asthma is a fat-soluble vitamin deficiency disease. Clin Exp Allergy 2008;38:385-7. https://doi. org/10.1111/j.1365-2222.2007.02920.x.

15 Zhang Y, Leung DY, Goleva E. Anti-inflammatory and corticosteroidenhancing actions of vitamin $D$ in monocytes of patients with steroid-resistant and those with steroid-sensitive asthma. J Allergy Clin Immunol 2014;133:1744-52.e1. https://doi.org/10.1016/j.jaci.2013.12.004.

16 Christensen JM, Cheng J, Earls P, et al. Vitamin D pathway regulatory genes encoding 1alpha-hydroxylase and 24-hydroxylase are dysregulated in sinonasal tissue during chronic rhinosinusitis. Int Forum Allergy Rhinol 2017;7:169-76. https://doi.org/10.1002/alr.21852.

17 Rostkowska-Nadolska B, Kusmierz D, Kapral M, et al. The change of proliferative potential of fibroblasts derived of nasal polyps in vitro cultured, influenced by derivatives vitamins $D$. Otolaryngol Pol 2007;61:661-7. https://doi.org/10.1016/S0030-6657(07)70503-6.
18 Rostkowska-Nadolska B, Sliupkas-Dyrda E, et al. Vitamin D derivatives: calcitriol and tacalcitol inhibits interleukin-6 and interleukin-8 expression in human nasal polyp fibroblast cultures. Adv Med Sci 2010;55:86-92. https://doi.org/10.2478/v10039-010-0012-9.

19 Rostkowska-Nadolska B, Fraczek M, Gawron W, et al. Influence of vitamin D(3) analogues in combination with budesonid R on proliferation of nasal polyp fibroblasts. Acta Biochim Pol 2009;56:235-42.

20 Lund VJ, Mackay IS. Staging in rhinosinusitus. Rhinology 1993;31:183-4.

21 Lund VJ, Kennedy DW. Quantification for staging sinusitis. The Staging and Therapy Group. Ann Otol Rhinol Laryngol Suppl 1995;167:17-21.

22 Moradzadeh K, Larijani B, Keshtkar A, et al. Normative values of vitamin D among Iranian population: a population based study. Int J Osteoporosis Metabolic Disorders 2008;1:8-15. https://doi.org/10.3923/ ijom.2008.8.15.

23 Ebrahimi M, Khashayar P, Keshtkar A, et al. Prevalence of vitamin D deficiency among Iranian adolescents. JPEM 2014;27:595-602. https:// doi.org/10.1515/jpem-2013-0428.

24 Wintergerst ES, Maggini S, Hornig DH. Contribution of selected vitamins and trace elements to immune function. Ann Nutr Metab 2007;51:301-23. https://doi.org/10.1159/000107673

25 Sigmundsdottir H, Pan J, Debes GF, et al. DCs metabolize sunlightinduced vitamin D3 to 'program' $T$ cell attraction to the epidermal chemokine CCL27. Nat Immunol 2007;8:285-93. https://doi. org/10.1038/ni1433.

26 Schlosser RJ, Soler ZM, Schmedes GW, et al. Impact of vitamin D deficiency upon clinical presentation in nasal polyposis. Int Forum Allergy Rhinol 2014;4:196-9. https://doi.org/10.1002/alr.21274.

27 Pinto JM, Schneider J, Perez R, et al. Serum 25-hydroxyvitamin D levels are lower in urban African American subjects with chronic rhinosinusitis. J Allergy Clin Immunol 2008;122:415-7. https://doi.org/10.1016/j. jaci.2008.05.038.

28 Wang LF, Lee CH, Chien CY, et al. Serum 25-hydroxyvitamin D levels are lower in chronic rhinosinusitis with nasal polyposis and are correlated with disease severity in Taiwanese patients. Am J Rhinol Allergy 2013;27:e162-5. https://doi.org/10.2500/ajra.2013.27.3948.

29 Mostafa Bel D, Taha MS, Abdel Hamid T, et al. Evaluation of vitamin $D$ levels in allergic fungal sinusitis, chronic rhinosinusitis, and chronic rhinosinusitis with polyposis. Int Forum Allergy Rhinol 2016;6:185-90. https://doi.org/10.1002/alr.21585.

30 Benetti C, Piacentini GL, Capristo C, et al. Microorganism-induced exacerbations in atopic dermatitis: a possible preventive role for vitamin D? Allergy Asthma Proc 2015;36:19-25. https://doi.org/10.2500/ aap.2015.36.3807.

31 Yenigun A, Dadaci Z, Oncel M. Plasma vitamin D levels of patients with allergic rhino-conjunctivitis with positive skin prick test. Am J Rhinol Allergy 2015;29:e46-9. https://doi.org/10.2500/ajra.2015.29.4164.

32 Stokes PJ, Rimmer J. The relationship between serum vitamin $D$ and chronic rhinosinusitis: a systematic review. Am J Rhinol Allergy 2016;30:23-2. https://doi.org/10.2500/ajra.2016.30.4267.

33 Lensmeyer GL, Wiebe DA, Binkley N, et al. HPLC method for 25-hydroxyvitamin D measurment:compartion with contemporaryassays. Clin Chem 2006;52:1120-6. https://doi.org/10.1373/clinchem.2005.064956.

Received: November 23, 2018 - Accepted: February 19, 2019

How to cite this article: Bavi F, Movahed R, Salehi M, et al. Chronic rhinosinusitis with polyposis and serum vitamin D levels. Acta Otorhinolaryngol Ital 2019;39:336-340. https://doi.org/10.14639/0392-100X-2439

Address for correspondence: Mehdi Bakhshaee, Sinus and Surgical Endoscopic Research Center, Emmam Reza Hospital, Faculty of Medicine, Mashhad University of Medical Sciences, Mashhad, Iran. Tel./Fax +98 51184134 92. E-mail: bakhshaeem@mums.ac.ir

This is an open access article distributed in accordance with the Creative Commons Attribution Non Commercial (CC BY-NC 4.0) license, which permits others to distribute, remix, adapt, build upon this work non-commercially, and license their derivative works on different terms, provided the original work is properly cited, appropriate credit is given, any changes made indicated, and the use is non-commercial. See: http://creativecommons.org/licenses/by-nc/4.0/. 